\title{
Revista \\ Coronavirus pandemic in light of nursing theories
}

\author{
Pandemia pelo coronavírus à luz de teorias de enfermagem \\ Pandemia de coronavirus a la luz de las teorias de enfermeira
}

Isabella Joyce Silva de Almeida' ORCID: 0000-0001-8360-5897

Poliana da Silva Lúcio" ORCID: 0000-0002-5022-0170

Marismar Fernandes do Nascimento ORCID: 0000-0001-7821-5077

Alexsandro Silva Coura"I ORCID: 0000-0002-0628-648X

'Universidade de Pernambuco. Petrolina, Pernambuco, Brazil "Universidade de Pernambuco. Recife, Pernambuco, Brazil "' Universidade Estadual da Paraíba. Campina Grande, Paraíba, Brazil

How to cite this article: Almeida IJS, Lúcio OS, Nascimento MF, Coura AS. Coronavirus pandemic in light of nursing theories.

Rev Bras Enferm. 2020;73(Suppl 2):e20200538 doi: http://dx.doi.org/10.1590/0034-7167-2020-0538

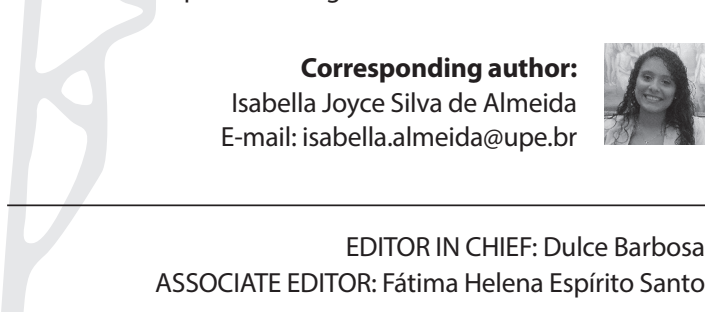

Submission: $05-18-2020$

Approval: 09-13-2020

\begin{abstract}
Objective: to reflect on the interface between the Coronavirus pandemic and nursing theories. Method: theoretical-reflective assay, anchored in the theoretical constructs of Dorothea Orem, Florence Nightingale and Callista Roy. Results: in the interface with Orem, the professional, based on the nursing systems, offers health education for the virus prevention, the conduct of home isolation and in high complexity assistance when there is worsening of COVID19; with Nightingale, it is revealed the importance of environmental sanitation, ventilation, personal and domestic cleaning and the surrounding areas; with Roy, focal stimuli are perceived such as the symptoms of COVID19, contextual stimuli related to comorbidities, and residual stimuli, concerning to work stress due to high viral transmission and lack of protective equipment. Final Considerations: nurses can use the theoretical framework of nursing theories as tools to guide their care in this pandemic situation.
\end{abstract}

Descriptors: Pandemics; Global Health; Coronavirus Infections; Nursing Theory; Nursing Care.

\section{RESUMO}

Objetivo: refletir sobre a interface entre a pandemia pelo coronavírus e as teorias de enfermagem. Método: ensaio teórico-reflexivo, ancorado nos constructos teóricos de Dorothea Orem, Florence Nightingale e Callista Roy. Resultados: na interface com Orem, o profissional, com base nos sistemas de enfermagem, oferece educação em saúde para prevenção ao vírus, manejo no isolamento domiciliar e assistência de alta complexidade, quando há o agravamento da COVID-19; com Nightingale, se desvela a importância do saneamento ambiental, ventilação, limpeza pessoal, doméstica e das áreas circunvizinhas; com Roy, se percebem os estímulos focais como os sintomas da COVID-19, estímulos contextuais relacionados às comorbidades, e estímulos residuais concernentes ao estresse laboral pela alta transmissibilidade virótica e insuficiência de equipamentos de proteção. Considerações Finais: o enfermeiro pode utilizar o arcabouço teórico das teorias de enfermagem como ferramentas para nortear o seu cuidado nesta conjuntura pandêmica.

Descritores: Pandemia; Saúde Global; Infecções por Coronavírus; Teoria de Enfermagem; Cuidados de Enfermagem.

\section{RESUMEN}

Objetivo: reflexionar sobre la interfaz entre la pandemia de coronavirus y las teorías de enfermería. Método: ensayo teórico-reflexivo anclado en los constructos teóricos de Dorothea Orem, Florence Nightingale y Callista Roy. Resultados: en la interfaz con Orem, el profesional, basado en sistemas de enfermería, ofrece educación en salud para la prevención del virus, manejo en aislamiento domiciliario y asistencia de alta complejidad cuando se presenta un agravamiento de COVID-19; con Nightingale, se revela la importancia del saneamiento ambiental, la ventilación, la limpieza personal y doméstica y de los alrededores; con Roy, se perciben los estímulos focales como los síntomas de COVID-19, los estímulos contextuales relacionados con las comorbilidades y los estímulos residuales relacionados con el estrés laboral por la alta transmisibilidad viral y el insuficiente equipo de protección. Consideraciones Finales: los enfermeros pueden utilizar el marco teórico de las teorías de enfermería como herramientas para orientar su atención en esta situación pandémica.

Descriptores: Pandemia; Salud Global; Infecciones por Coronavirus; Teoría de Enfermería; Atención de Enfermería. 


\section{INTRODUCTION}

The disease caused by the Coronavirus SARS-CoV-2, also known as Coronavirus Disease 2019 (COVID-19), brings symptoms such as fever, dry cough and fatigue, which can progress to dyspnea and, and in more severe cases, Severe Acute Respiratory Syndrome. Transmission occurs through the air, close personal contact or with objects and surfaces contaminated with secretions by droplets of saliva, sneezing, coughing, followed by mouth, nose or eye contact ${ }^{(1)}$.

Therefore, the current situation of Pandemic by Coronavirus is considered by the World Health Organization (WHO) as a global public health emergency due to its high transmission, virulence and potential for aggravation in the clinical condition, also to the negative effects in the health systems worldwide, which are likely to the imminent collapse ${ }^{(2-3)}$.

Consequently, global health, on a par with the peculiarities of the health systems of each country, calls for the diligent reorganization of the care network, creation of clinical protocols, development of scientific studies and professional training, aiming to respond appropriately to the abrupt demands coming from COVID-19 $9^{(1,3)}$.

When considering that the nurse has a relevant role in the line of coping with this global health emergency, it is essential to foster a critical look at nursing care, within the health care network, linked to conceptual constructs that provide a theoretical-scientific framework basis for care practice ${ }^{(2-3)}$.

In this perspective, nursing theories emerged to strengthen as a science, to guide care practice, management, teaching and research in this area, which through its use, nurses are prepared for systematic, critical, reflective, humanized, ethical and holistic care, covering biopsychosocial aspects of the individual, family and community, to legitimize the integrality, universality and equity, proposed by the Unified Health System(SUS) ${ }^{(4-5)}$.

Thus, the genesis of theories happens in the practical field, when concerns and/or demands that lay in the common sense of the professionals break the contemplative chain and move on to a critical-reflexive analysis of reality. It is in this transition that there is the consolidation of nursing as a science, identifying inherent phenomena in the practice of nurses and clarifying concepts that need to be properly defined, so that the processes of nursing care are based on a solid theoretical framework, strengthening the praxis ${ }^{(6)}$.

Although most theories have been developed in the past century, their constructs transcend time and become relevant to the current scenario. In this perspective, despite the recognition of other theories, it was considered relevant to bring Dorothea Orem Theory in this present study, due to the user's co-responsibility; the theory of Florence Nightingale, when considering that it indicated assumptions that emerge in the current guidelines; the theory of Callista Roy, for indicating adaptive processes that urge when facing habits change and the current psychological burden essential to restrain a pandemic such as COVID-19.

Therefore, the following question emerges: how can the theoretical framework of nursing be applied to guide the practice of nurses, in the current pandemic scenario? Thus, the objective was to reflect on the interface between the Coronavirus pandemic and nursing theories.

\section{METHOD}

This is a study of the theoretical-reflective assay type, carried out during April and May 2020, anchored in the theoretical constructs of Dorothea Orem (Systems Theory), Florence Nightingale (Environmental Theory) and Callista Roy (Adaptation Theory).

Two phases were developed: I - a narrative review of the literature on the subject, by accessing the primary works that support the theoretical-methodological framework, government documents and scientific articles; II - reflection about the interface between the Coronavirus pandemic and nursing theories, based on the literature found and the researchers' experience.

The main data of the analysis were summarized, according to Chart 1, involving the most prominent aspects of reflection regarding the interface of the theories selected to guide care in this pandemic situation, and in subthemes according to the conceptual perspective of each theory.

Chart 1 - Summary of the interface between the theories of Orem, Nightingale and Roy and the pandemic by Coronavirus, 2020

\begin{tabular}{|c|c|c|c|}
\hline \multicolumn{3}{|c|}{ CONCEPTS } & INTERFACE FACING COVID-19 \\
\hline \multirow{3}{*}{ 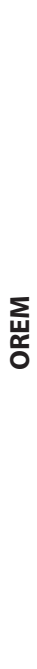 } & \multirow{3}{*}{ 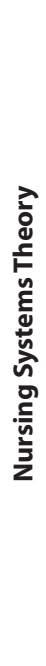 } & $\begin{array}{l}\text { Education } \\
\text { support }\end{array}$ & $\begin{array}{l}\text { Health education for virus prevention } \\
\text { Frequent hand washing } \\
\text { Use of alcohol-based hand sanitizer } \\
\text { Respiratory protocol when sneezing or } \\
\text { coughing } \\
\text { Avoid touching the face, especially eyes, } \\
\text { nose and mouth } \\
\text { Keep a minimum distance of two meters } \\
\text { from people }\end{array}$ \\
\hline & & $\begin{array}{l}\text { Partially } \\
\text { compensatory }\end{array}$ & $\begin{array}{l}\text { Management of household isolation } \\
\text { Separation of personal items such as } \\
\text { silverware and towels } \\
\text { Restriction of the patient to a room in the } \\
\text { house and with a mask Home caregiver } \\
\text { wearing a surgical mask } \\
\text { Change the mask within two hours or } \\
\text { when it becomes moist }\end{array}$ \\
\hline & & $\begin{array}{l}\text { Totally } \\
\text { compensatory }\end{array}$ & $\begin{array}{l}\text { High complexity care with aggravation of } \\
\text { Covid-19 } \\
\text { Comprehensive care }\end{array}$ \\
\hline 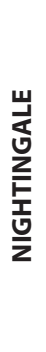 & 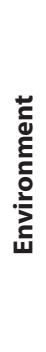 & $\begin{array}{l}\text { Environmental } \\
\text { hygiene }\end{array}$ & $\begin{array}{l}\text { Care for environmental sanitation } \\
\text { Ventilation } \\
\text { Personal hygiene } \\
\text { Household cleaning } \\
\text { Daily house cleaning with } 70 \% \text { isopropyl } \\
\text { alcohol } \\
\text { Cleaning of residence's surrounding areas } \\
\text { Handwashing } \\
\text { Care for equipment brightness and noise } \\
\text { Nutrition care } \\
\text { Bed care and sheets with regular change }\end{array}$ \\
\hline \multirow{3}{*}{ రે } & \multirow{3}{*}{ 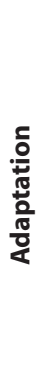 } & Focal stimulus & $\begin{array}{l}\text { Covid-19 symptom management (fever, } \\
\text { dry cough, fatigue) } \\
\text { Perception of worsening with severe } \\
\text { dyspnea }\end{array}$ \\
\hline & & $\begin{array}{l}\text { Contextual } \\
\text { stimulus }\end{array}$ & $\begin{array}{l}\text { Comorbidities (diabetes, hypertension, } \\
\text { respiratory disease) } \\
\text { Consideration of workplace prone to } \\
\text { transmission }\end{array}$ \\
\hline & & $\begin{array}{l}\text { Residual } \\
\text { stimulus }\end{array}$ & $\begin{array}{l}\text { Smoking } \\
\text { Work stress due to high viral transmission } \\
\text { Concern on lack of protective equipment }\end{array}$ \\
\hline
\end{tabular}


Chart 1 (concluded)

\begin{tabular}{|c|c|c|c|}
\hline \multicolumn{3}{|c|}{ CONCEPTS } & INTERFACE FACING COVID-19 \\
\hline \multirow[b]{2}{*}{ ఫ } & \multirow{2}{*}{$\frac{\substack{\frac{2}{0} \\
\frac{0}{0}}}{\frac{0}{0}}$} & $\begin{array}{l}\text { Regulatory } \\
\text { coping }\end{array}$ & Search for homeostasis of the organism \\
\hline & & $\begin{array}{l}\text { Cognate } \\
\text { coping } \\
\text { Adaptive } \\
\text { Process }\end{array}$ & $\begin{array}{l}\text { Support in psychological and spiritual aspects } \\
\text { Self-knowledge about the role in society } \\
\text { Encouraging the bonds' strengthening } \\
\text { Search for adaptive responses }\end{array}$ \\
\hline
\end{tabular}

\section{COVID-19 Pandemic Interface and Dorothea Orem Theory}

Nurse Dorothea Orem developed the theory entitled "Theory of self-care deficit", supported/composed of three other theories: self-care theory; self-care deficit theory; and nursing systems theory. They correlate intending to give full meaning to the theory ${ }^{(6-7)}$.

Self-care is defined as the individual's ability to perform actions for his/her benefit. When it is not completely accomplished or when the demands exceed the individual's basic skills concerning the activities, the self-care deficit is characterized, with consequent demand for nursing action ${ }^{(7)}$.

The Nursing Systems Theory expose nursing actions, according to the patient's needs, so there are three possible classifications: Totally Compensatory System, when the patient depends completely on the nurse's actions; Partially Compensatory System, when the patient is partially dependent, showing partial ability to develop some actions that provide them with self-care; and Support-Education System, when the patient can carry out self-care, the role of the nurse regarding the guidelines being preeminent $^{(6-7)}$.

Concerning nursing care facing the Coronavirus pandemic, associating it to the possible stages that the patient may be in, the professional manages to be introduced in several scenarios, ranging from community prevention guidelines to COVID-19, to high complexity assistance, in cases where the disease worsens.

When considering the perspective of self-care mentioned in this theory, the nurses' attitudes foster the patient's autonomy, a crucial element for their empowerment when facing their health decisions. Furthermore, health education highlights, a tool that enables the construction of knowledge by the user and collectivities, given their self-care, through the Support-Education System ${ }^{(7)}$.

In this perspective, the nurse can guide the following types of care: frequent hand washing or when it is impossible to wash, alcohol-based hand sanitizer; respiratory protocol when sneezing or coughing, covering mouth and nose with tissue paper or with the inner side of the arm; avoid touching the face, especially eyes, nose and mouth; and keep a distance of at least two meters from people who cough or sneeze ${ }^{(1)}$.

While the individual does not worry about self-care, he/she can become sick, which may express itself mildly or severely. If it evolves mildly, it demands action under the Partially Compensatory System, in which the nurse assists, and, concomitantly, the patient can also perform some actions that show a certain degree of independence and self-care.

Thus, the professional provides guidance that goes beyond the basic and includes the management of home isolation, which includes the separation of personal use objects, such as silverware, glasses or plates and even a face towel; the importance of restricting the patient to a room in the house and, if it is not possible, that the patient continuously wears a surgical mask; when dealing with the patient, the home caregiver should use the surgical mask, staying with it for up to two hours or even when it becomes moisty; daily cleaning of the house with $70 \%$ isopropyl alcohol, especially in places frequently touched such as door handles, switches, remote controls, among others ${ }^{(1)}$.

Regarding the individual who worsens in the manifestations of the Coronavirus, characterized mainly by the Severe Acute Respiratory Syndrome, this situation calls for assistance that fits with the Totally Compensatory System. In this context, nurses develop their clinical practice in line with the demands of high complexity care, providing constant care, because many patients, at this level of complication, are unable to perform any action that brings them any benefit.

\section{COVID-19 Pandemic Interface and Florence Nightingale's Theory}

The existence of respiratory syndromes takes place seasonally throughout the world, however the rise of the pandemic, which is characterized by high infecting, transmission/ing and morbidity and mortality, has caused health authorities and the scientific community to review the importance of protective measures to control respiratory diseases.

Thus, the Environmentalist theory of nurse Florence Nightingale, brings along postulates that transcend time and become vital observations for prevention measures for transmission of the SARS-CoV-2 Coronavirus and the nursing care to infected patients.

Under the perspective of disease prevention and health promotion, the postulates considered by the theory emphasize a point called "home health", which deals with the importance of basic sanitation, ventilation, household cleaning and the influence of the cleaning of the residence's surrounding areas. Also, they suggest the importance of personal hygiene, considering that many microorganisms communicate through the skin. Finally, they highlight the need for handwashing ${ }^{(6,8)}$.

The preference for environmental and personal hygiene in Nightingale's theory brings to date the usual practice in health, standing out the current practice experienced in the pandemic period by COVID-19, when the preventive measures adopted guiding for the hygiene of people and environments, also to the isolation of the individuals, through social distancing and, in extreme cases, lockdown, which is configured as the total blocking of non-essential activities ${ }^{(1)}$.

However, Florence's view was, inevitably, hospital centered, so that most of her postulates are related to the patient in the context of the secondary and tertiary level. Thus, they were focused on light, noise, nutrition and bed care, among other environmental aspects ${ }^{(6)}$.

To patients hospitalized in Intensive Care Units (ICUs), due to the worsening of the symptoms of Coronavirus infection, environmental factors such as brightness, noise from infusion pumps, monitors, mechanical fans, vacuum cleaners and other equipment interfere with the patient's sleep and rest. Therefore, it is necessary to minimize this condition that can hinder therapy, especially for those who are without sedation, besides be a stress 
factor for the health team, especially the nursing team that encourages comprehensive and continuous assistance ${ }^{(9)}$.

Another issue reported by the environmental theory is about bedding. It is observed that the guidelines given in the $19^{\text {th }}$ century are still relevant nowadays, as it was addressed that there should be a periodic change of sheets, with a concern to infection control, and proper storage of them, avoiding folds that could form pressure points, favoring pressure sores for the patient ${ }^{(6)}$. These types of care are relevant and must be considered, aiming at positive nursing assistance to the patient submitted to high complexity care, related to the complications of the symptoms of COVID-19.

Therefore, Florence Nightingale's observations foster an accurate nursing process, so that the holistic view, humanization, and criticality are considered, when the environment in which the patient is inserted becomes an object of attention and reflection. The transcendence of these orientations in time and space legitimizes the nursing approach to these theoretical postulates, aiming at a successful confrontation of this pandemic.

\section{COVID-19 pandemic interface and Callista Roy's Theory}

Nurse Callista Roy's adaptation model is based on the four meta paradigms common to other nursing theories, which are the assumptions related to the person, the environment, health, and nursing. As for the person, the theorist states that the person is submitted to a scheme that includes the stimulus, which generates the coping mechanisms and results in the response of the individual, family or community, which end up supporting another stimulus ${ }^{(6,10)}$.

Detailing this scheme, Roy observed that stimulus can be of three types: focal, contextual, and residual. Therefore, in the context of the Coronavirus pandemic, the correct management of focal stimulus is necessary, covering the signs and symptoms of respiratory infection, such as fever, dry cough, fatigue, among other symptoms that signal to worsen of the case, such as severe dyspnea(2).

Concerning contextual stimulus, they can be defined with comorbidities, such as diabetes, hypertension, pre-existing respiratory disease, immunosuppression, and a workplace prone to transmission. Regarding residual stimulus, they are defined as internal and external factors, seen as smoking, work-related stress, stress-related to high viral transmission, as well as stress-related to the absence and/or limited access to appropriate Personal Protective Equipment (EPI) $)^{(1)}$.

When it comes to coping mechanisms, they are subdivided as regulators and cognates ${ }^{(6,10)}$. Regulators include the physiological mode, which dialogues directly with the individual's physiology, revealing aspects related to the organism's situation and function ${ }^{(10)}$. In the infection by the Coronavirus SARS-CoV-2, this point is relevant, because the body homeostasis is directly related to the less probability of worsening of the symptoms due to the virus infection ${ }^{(3)}$.

The cognate coping mechanisms pass through modes defined as Self-concept, Role Function, and Interdependence. The Self-concept mode defines coping as an imminent demand to maintain psychic integrity, with a focus on psychological and spiritual aspects. Certainly, considering the context of panic and anxiety that this pandemic generates, the confront of emotional support in chaotic times, ease the anguish and favors the psychological well-being.

Regarding the coping mechanism that works with the Role Function mode, it refers to the individual's ability to understand his/her role in the world, self-knowledge that allows identifying his/her role in society. In times of pandemic, this acknowledgment is necessary, because the population that does not participate in essential services give supports to measures control when it fulfills social isolation, whereas in the scope of essential services, health professionals, for example, legitimate their functional importance when they perform their duty with technical skills and humanization ${ }^{(3)}$.

The coping mechanism of the interdependence mode brings the affective demands of everyone. In fact, with the proposal of social distancing it is common to observe anguish on the community, which has a peculiar demand to relate, for complete well-being. However, information and communication technologies can be an alternative to mitigate physical distance and their respective repercussions on the population's biopsychosocial health.

Still about the interdependence mode, it is necessary to think what health professionals, especially nursing, who are at the frontline in facing this pandemic, are going through this current situation, as many of these professionals are unable to return to their homes, have contact with relatives and friends and constantly experience the fear of transmission, the exhaustive workload and the precarious infrastructure of many health institutions. This flagellant context that, considering Roy's assumptions, directly interacts in the confrontation of this group, needs to be better addressed by health authorities.

Concerning the responses that reflect the individual's adaptive process, they are subdivided into adaptive and ineffective. The adaptive ones promote the integrity of the human being, positively affecting health. The ineffective response, on the other hand, is when the individual is unable to coping effectively, compromising his/her self-care and development ${ }^{(6,10)}$. Therefore, it is through the answers that the nurse can identify the individual's coping mechanisms. Therefore, interventions are designed to obtain adaptive responses ${ }^{(6,10)}$.

Thus, considering this difficult moment of world health, the nurse who seeks appropriate actions, guided by science, reflection and criticality, needs to consider the constructs of Dorothea Orem (Systems Theory), Florence Nightingale (Environmental Theory) and Callista Roy (Adaptation Theory), because through their assumptions a view that contemplates the individual in its entirety is proposed, making up a singular path, in which the science that deals with caring can carry out to guarantee the accuracy of their responses.

\section{Study limitations}

The possible limitations are related to the use of only three theories to dialogue with the theoretical framework of nursing and the Coronavirus pandemic. Considering that there are several other nursing theories, which would support a solid and relevant reflection for this study. Therefore, it is suggested to foster reflections, contemplating constructs from other nursing science theorists. 
Also, many aspects related to COVID-19 are not permanently defined, which can lead to changes in guidelines and/or protocols as advances in scientific findings are made.

\section{Contributions to Nursing}

Encourage nurses to recognize the bases that support nursing praxis and, thus, enlighten the theories presented here as tools for the conscious, critical and reflective application of the Nursing Process in this pandemic conjuncture and, thus, make possible the quality of care.

\section{FINAL CONSIDERATIONS}

The current pandemic scenario calls for scientific attitudes that are appropriate in the coping process. In this context, the nurse who participates in the frontline of assistance, has conceptual frameworks to guide their care in a critical, reflective, systematic, and comprehensive way.

From this perspective, it was possible to understand the interface of the theories mentioned before the pandemic by COVID-19, to indicate that care actions can be guided by assumptions and concepts. Thus, the theoretical constructs of Dorothea Orem, Florence Nightingale and Callista Roy, envision a performance of nursing in different aspects, contemplating the individual, the family and the community in their health needs from the biopsychosocial perspective.

Furthermore, to diversify and qualify the scientific publishing of nursing, consolidating its theoretical-scientific framework, to strengthen praxis, it is suggested that this theme draw interest so that new studies can be carried out, especially concerning the conducting investigations that can empirically test the usefulness of these theories in the care of COVID-19.

\section{REFERENCES}

1. Ministério da Saúde (BR). Secretaria de Ciência, Tecnologia, Inovação e Insumos Estratégicos em Saúde. Diretrizes para diagnóstico e tratamento da COVID-19. Brasília (DF);2020.

2. Organização Mundial de Saúde. Folha informativa - COVID-19 (doença causada pelo novo Coronavírus) [Internet]. OPAS: Brasil; 2020 [cited 2020 Apr 20]. Available from: https://www.paho.org/pt/covid19

3. Rafael RMR, Neto M, Carvalho MMB, David HMSL, Acioli S, Faria MGA Epidemiology, public policies and Covid-19. Rev Enferm UERJ, Rio de Janeiro, 2020;28:e49570. doi: 10.12957/reuerj.2020.49570

4. Salviano MEM, Nascimento PDFS, Paula MA, Vieira CS, Frison SS, Maia MA, et al. Epistemology of nursing care: a reflection on its foundations. Rev Bras Enferm. 2016;69(6):1172-7. doi: 10.1590/0034-7167-2016-0331

5. Brandão MAG, Barros ALBL, Primo CC, Bispo GS, Lopes ROP. Nursing theories in the conceptual expansion of good practices in nursing. Rev Bras Enferm. 2019;72(2):604-8. doi: 10.1590/0034-7167-2018-0395

6. Mcewen M. Bases Teóricas de enfermagem. Porto Alegre: Artmed; 2016. 608p.

7. Orem DE. Nursing: concepts of practice. Saint Louis: Mosby; 2001. 542p.

8. Nightingale F. Notas sobre enfermagem: o que é e o que não é. São Paulo: Cortez; 1989. 174p.

9. Younis MB, Hayajneh F, Rubbai Y. Factors influencing sleep quality among Jordanian intensive care patients. Br J Nurs. $2020 ; 29(5): 298-302$. doi: 10.12968/bjon.2020.29.5.298

10. Roy SC, Andrews HA. The Roy adaptation model. Londres: Pearson; 2008. 576p. 